\title{
Effect of Different Types of Extractants in the Separation of Rare Earth Metals using Emulsion Liquid Membrane Method: A Review
}

\author{
Ninda Anisyabana, *Anni Anggraeni, Uji Pratomo \& Riska A. Fadiyah \\ Jurusan Kimia/FMIPA - Universitas Padjadjaran, Sumedang - Indonesia 45363 \\ Received 26 March 2021, Revised 22 April 2021, Accepted 25 May 2021 \\ doi: $10.22487 /$ j24775185.2021.v10.i2.pp105-118
}

\begin{abstract}
Rare earth metals (REMs) are minerals needed in modern technology because they have unique chemical, catalytic, electrical, and paramagnetic properties, so REMs have the potential in various field applications. The similarity in the physical and chemical properties of REMs causes the separation process from their parent minerals hard occurred. Emulsion liquid membrane is an effective and efficient method for REMs purification and separation because in practice it only requires a small amount of solvent, the diffusion rate, and mass transfer are high, fast, and simultaneous compared to the solvent extraction method which requires many extraction steps and requires many the solvents. In the emulsion liquid membrane method, one of the factors that can determine the success of the extraction process is the ligandslextractants selectivity used. The extractants should be highly selective against the target REM ions, both in the external aqueous phase and the internal aqueous phase. Therefore, this review aimed to determine various types of extractants selectivity, such as D2EHPA, Cyanex 302, Cyanex 572, $(\mathrm{RO})_{2} \mathrm{P}(\mathrm{O}) \mathrm{OPh}-\mathrm{COOH}$, aniline, and TBP on extraction efficiency and stripping efficiency in the separation of rare earth metals through the emulsion liquid membrane method.
\end{abstract}

Keywords: Rare earth metals, emulsion liquid membrane, extractants

\section{Introduction}

Rare earth metals (REMs), also known as lanthanide elements, are metals abundant in nature, but they are found in relatively small amounts and have limited distribution (Binnemans et al., 2013; Suprapto, 2009).

REM in its pure condition is high value because it has the potential to support modern technology so that in recent years the demand for REM has increased, this is due to its unique properties such as paramagnetic, optical, electrical, and special electronic structures that make REM potential for application in various fields (Pusztai et al., 2013; Larquet et al., 2017) including permanent magnets, metallurgy, autocatalysts, glass additives and ceramic applications (Asnani \& Patra, 2013). In addition, it can be widely used in various high-tech products and industries such as aerospace, military systems, and wind turbines (Hoenderdaal et al., 2013; Srinivasan et al., 2017). However, REM has similar physical and chemical properties between one element to another, which causes the separation process from their parent minerals hard occur (Jolly, 1975). Therefore we need an effective and efficient separation method to obtain REM in its pure condition.
Conventional methods that can be used in REM separation are deposition, reverse osmosis, adsorption, ion exchange, and solvent extraction (Liang et al., 2011). Solvent extraction is the method most often used on an industrial scale (Kumbasar, 2008) because it is simple and the results of the separation are good, but this technique is less efficient because it requires many extraction stages, high operating costs, and high solvent consumption so that it is not environmentally friendly and uneconomical (Wang et al., 2017; Ritcey \& Ashbrook, 1979). Therefore, the solvent extraction method is expanded into a liquid membrane-based technology using emulsion liquid membrane (ELM), where this method is economical because it only requires a small amount of solvent, simple operation with high-efficiency and selectivity, high diffusion rate and mass transfer, low energy consumption, simultaneous and fast because the extraction and stripping processes occur in one stage (Balasubramanian, 2017; Laki et al., 2015; Hirai \& Orikoshi, 2004; Chaouchi \& Hamdaoui, 2014). The ELM selectivity depends on the extractant used (Othman et al., 2006). ELM is a three-phase dispersion system, which consists of an external phase, a membrane, and an internal phase in the form of a double emulsion. The solute from

\footnotetext{
${ }^{*}$ Correspondence:

Anni Anggraeni

e-mail: ninda17001@mail.unpad.ac.id

(c) 2021 the Author(s) retain the copyright of this article. This article is published under the terms of the Creative Commons Attribution-NonCommercial-ShareAlike 4.0 International, which permits unrestricted non-commercial use, distribution, and reproduction in any medium, provided the original work is properly cited.
} 
the external phase is transported to the internal phase through the membrane phase. The membrane phase is an organic phase that contains a carrier (extractant) together with surfactants to stabilize the primary emulsion granules. The primary emulsion is made by dispersing the internal phase in the membrane phase. This emulsion is then dispersed under stirring to an external phase containing the solute to be separated (Kargari, 2013; Choudhury et al., 2010).

The solute in the form of metal ions contained in the external solution forms a complex with the extractant at the membrane-external phase interface. The complex formed is transported through the membrane phase to the internal-membrane phase interface leading to the internal phase. Selectivity for the desired metal is often increased by introducing a carrier/extractant that fits into the membrane.

Extractant selectivity affects the extraction yield. The extractants must be highly selective towards the target metal ions, both in the external and internal aqueous phases (Chakraborty et al., 2010). The extractant works as an activator to transport the desired solute from the feed phase to the internal phase. The carrier concentration has an important role in the transport behavior, membrane stability, selectivity, and extraction efficiency of the ELM process. Therefore, this review article discusses the effect of various types of extractants concentration based on their chemical properties to determine their selectivity to extraction yields in the separation of rare earth metals using the Emulsion Liquid Membrane method.

\section{Results and Discussion}

\section{Extractants}

Extractants known as ligands are electron donors that are selective towards the target metal ion, which is an electron acceptor, to form a complex compound (Sari, 2017). In the emulsion liquid membrane process, the extractants act as a carrier that facilitates the mass transfer of rare-earth ions from the feed solution to the receiving solution through the membrane for the separation process (Kolev, 2005).

Most of the extractants are viscous. Thus a diluent is needed to dissolve the extractant and ensure good contact between the extractant and the water phase. Examples of various types of diluents that are often used include kerosene, n-hexane, benzene, dichloromethane, and chloroform. Each diluent gives a different equilibrium constant value depending on the extraction mechanism (Zhang et al., 2016a).

The synthesis process or the selection of extractants must follow several criteria to obtain a good separation. Most importantly, the extractant must have at least one functional group and a relatively long hydrocarbon chain or ringsubstituted element. Functional groups such as $\mathrm{P}, \mathrm{N}$, $\mathrm{O}$, or $\mathrm{S}$ act as metal complexes with REM, while carbon chains are used to intensify the extractant's solubility in the solvent used. In addition, a good extractant must have positive selectivity to the desired REM, excellent chemical stability, low density and viscosity, and large surface tension (Zhang et al., 2016a).

The most widely used extractants for the separation of REM are organophosphorus-based extractants. Organophosphorus acid extractants such as 2-ethylhexyl phosphoric acid mono 2ethylhexyl ester (EHEHPA or also known as PC88A), di-(2-ethylhexyl) phosphoric acid (D2EHPA), and bis-2,4,4-trimethyl pentyl phosphate acid (Cyanex 272) is widely used commercially for the separation and purification process of REM because of its low water solubility, also has good chemical stability and solvation properties. To obtain high selectivity, an extractant must have a very specific affinity for one component (Swain \& Otu, 2011; Yoon et al., 2015; Anitha et al., 2015; Wannachod et al., 2015a; Wannachod et al., 2015b).

\section{Classification of extractants}

Based on their chemical properties, extractants are broadly classified into the following three categories (Perera \& Stevens, 2009; Zhang et al., 2016b).

\section{Acid extractants}

In general, the metal-binding mechanism with acidic extractants follows the cation exchange mechanism. Acid extractants consist of:

a) Organophosphoric acid (for examples: Cyanex 272, DTPA, Cyanex 572, Cyanex 302, PC88A/EHEHPA, D2EHPA/P204, Ionquest 801)

b) Carboxylic acid (for example: $(\mathrm{RO})_{2} \mathrm{P}(\mathrm{O}) \mathrm{OPh}$ $\mathrm{COOH})$ )

\section{Anionic extractant}

In anionic extractants, the extraction process depends on the ability of metal ions to form anionic species in the external phase. The metal is extracted as an ion pair by the amine salt. Anionic extractants consist of:

a) Quaternary ammonium salt (for example, Aliquat 336 / TOMAC)

b) Primary amines (for example, aniline)

c) Tertiary amines (for example, TOA, TNOA, Alamine 336)

\section{Solvent extractants}

The solvent extractant competes with the aqueous phase as the first solvent shell around the metal ion, which facilitates the transfer of the metal ion complex into the membrane phase. The solvent extractant consists of:

a) Phosphine oxides (for example: TOPO/ Cyanex 921)

b) Phosphorus esters (for example: TBP). 
Extractants types for REM separation in the ELM system

The following are various types of extractants that are commonly used based on their chemical properties for the separation of rare earth metals in the emulsion liquid membrane system: D2EHPA

The most commonly used extractant for REM separation from the organophosphorus group is di(2-ethylhexyl) phosphoric acid or also known as D2EHPA/P204. This extractant is a colorless or yellowish liquid with non-polar properties.
D2EHPA can reduce the overall number of extraction steps required in REM separation (Ismail et al., 2019).

D2EHPA is also known as a cation-exchange extractant, which is similar to most other organophosphorus acids. This is because the metal replaces the hydrogen ions in the extractant and produces a dissolved organic complex that has a neutral charge. The compound structure of D2EHPA is shown in Figure 1.

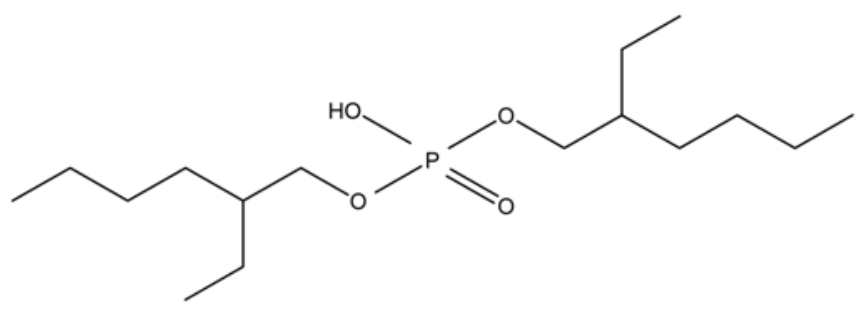

Figure 1. D2EHPA structure (di-(2-ethylhexyl) phosphoric acid $/ \mathrm{P}_{2} \mathrm{O}_{4}$ : dioctyl phosphate

In his research, Sato (1989) concluded that REM with D2EHPA follows a cation exchange mechanism in low acidity and a solvent mechanism in high acidity. D2EHPA shows higher extraction efficiency for metals with a larger atomic number in the lanthanide series; $\mathrm{La}<\mathrm{Ce}<\mathrm{Pr}<\mathrm{Nd}<\mathrm{Sm}<\mathrm{Eu}$ $<\mathrm{Gd}<\mathrm{Tb}<\mathrm{Dy}(-\mathrm{Y}<\mathrm{Ho}<\mathrm{Er}<\mathrm{Tm}<\mathrm{Yb}<\mathrm{Lu}$. This indicates that the extraction efficiency is proportional to the REM atomic number for a particular organophosphorus acid due to the anion extractants attraction effect and an increased electrostatic force that causes the size of the cations to be smaller (Gupta \& Krishnamurthy, 2005).
In emulsion liquid membrane systems, the concentration of ligands or extractants plays a major role in the transport behavior and membrane stability, among all other parameters. The extractant concentration used must be optimized to obtain high extraction and stripping efficiency. Too high or too low extractant concentrations can reduce the extraction and stripping efficiency. The extraction efficiency and stripping efficiency in the emulsion liquid membrane method can be calculated through equations (1) and (2) as follows (Davoodi-Nasab et al., 2018b):

$$
\begin{aligned}
& \% \mathrm{E}=\left(\frac{(\text { VFaeo.CFaeo })-(\text { VFae.CFae })}{(\text { VFaeo.CFaeo })}\right) \times 100 \% \\
& \% \mathrm{~S}=\left(\frac{\text { CFai.VFai }}{(\text { VFaeo.CFaeo })-(\text { VFae.CFae })}\right) \times 100 \%
\end{aligned}
$$

Where Vfaeo is the external phase volume before extraction, Vfae is the external phase volume after extraction, Cfaeo is the external phase concentration before extraction, Cfae is the external phase concentration after extraction, Cfai is the final concentration of the internal phase, and Vfai is the final volume of the internal phase.
Figure 2 shows the effect of D2EHPA extractant concentration on the Gd(III) extraction yield carried out by Davoodi-Nasab et al. (2018b). The extraction efficiency of Gd(III) can be increased by increasing the D2EHPA concentration from 0.005 to $0.05 \mathrm{M}$. It can be attributed to sufficient free extractant access and an unsaturated interface between the feed phase and the membrane for 
extraction (Alpaydin et al., 2011; Othman et al., 2006).

Increasing the D2EHPA concentration further from 0.05 to $0.5 \mathrm{M}$ did not improve the extraction performance and led to a decrease in the extraction efficiency of Gd(III). This is due to a decrease in the rate of the stripping reaction. Gd(III) remains uncomplicated in the membrane phase and causes a reduction in the final yield. In addition, increasing the extractant concentration could further decrease the emulsion stability. According to Sabry et al. (2007), this occurs due to the nature of the extractant interface and the opposite nature of the extractant and surfactant. In addition, increasing the higher concentration of extractants can also increase the membrane viscosity, which leads to forming larger emulsion clumps, thus slowing the diffusion rate and causing membrane swelling, which can dilute the stripping phase (Kumbasar \& Tutkun, 2006).

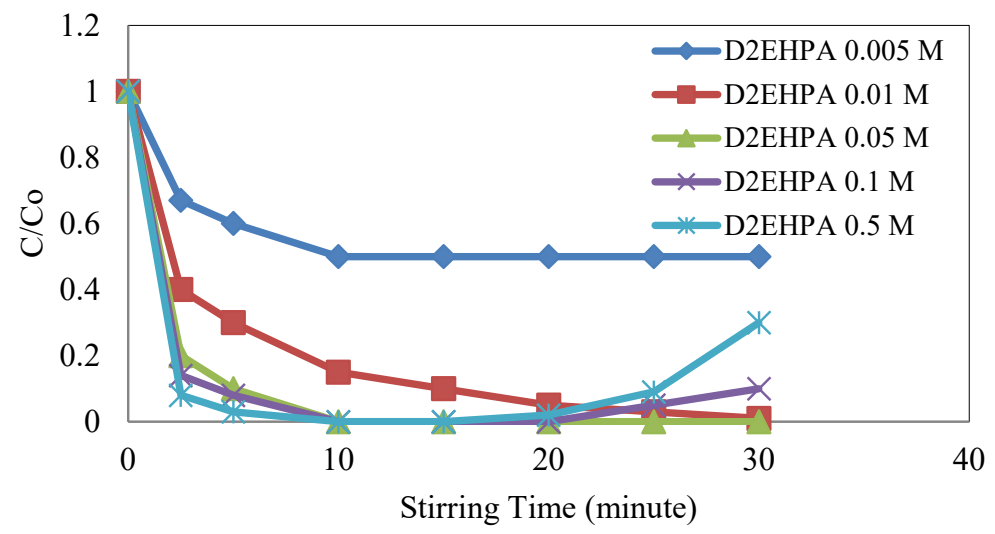

Figure 2. Effect of extractant concentration and stirring time on extraction Gd(III) (adopted from research Davoodi-Nasab et al., 2018a)

Based on an economic point of view, a lower concentration of extractants is more profitable (Chaouchi \& Hamdaoui, 2015) because the extractant is the most expensive agent among the other components of the ELM system. Therefore, $0.05 \mathrm{M}$ was determined as the optimal concentration value for D2EHPA as the extractant resulting in higher stability and extraction efficiency of Gd(III). The extraction efficiency and stripping efficiency of $\mathrm{Gd}(\mathrm{III})$ were 99 and $79 \%$, respectively.

Raji et al. (2017b) also conducted an ELM study by varying the D2EHPA concentration in the range of 0.005 to $0.5 \mathrm{M}$ against the $\mathrm{Dy}(\mathrm{III})$ extraction yield. The results show that the extraction efficiency of Dy(III) increases by increasing the D2EHPA concentration from 0.005 to $0.5 \mathrm{M}$.

It comes from the formation of more DyD2EHPA complexes at the outer interface between the feed phase and the membrane phase, resulting in increased diffusion of $\mathrm{Dy}(\mathrm{III})$ through the membrane (Raji et al., 2017b). The $0.05 \mathrm{M}$ D2EHPA concentration was chosen as the best extractant concentration based on the experimental results. The maximum extraction efficiency and stripping efficiency of Dy(III) were $99.6 \%$ and $85.22 \%$, respectively.

Based on the research of Basuki \& Pamungkas (2019), D2EHPA concentration was important to determine the metal transfer mechanism in the internal phase because, with the increased D2EHPA concentration, the internal phase concentration of the REM will be increase. Therefore, the reaction with D2EHPA and metal will be better. To determine the effect of REM transfer on the organic phase, it can be seen in the binding ability of D2EHPA and REM to be separated. REM is initially in the external aqueous phase in a complex form that is dissolved with water and aqueous solutions such as nitrates. Furthermore, the extraction process is replaced by D2EHPA because the D2EHPA ligand is in contact with $\mathrm{H}_{2} \mathrm{O}$ and forms a neutral complex in the organic phase. This shows that the more REM is extracted, the more neutral complexes are formed with D2EHPA in the membrane phase.

The following is an example of the reaction that occurs in the $\mathrm{Y}$ and Dy extraction process in each acidic medium, which can be written as equations (3) and (4) (Setyadji \& Purwani, 2018):

$$
\begin{aligned}
& \mathrm{Y}^{3+}+3 \mathrm{NO}^{3-}{ }_{(\mathrm{a})}+3 \mathrm{H}_{2} \mathrm{~A}_{2} \rightleftharpoons\left(\mathrm{HA}_{2}\right)_{3(o)}+3 \mathrm{H}^{+}+3 \mathrm{NO}^{3-} \\
& \mathrm{Dy}^{3+}+3 \mathrm{NO}^{3-}{ }_{(\mathrm{a})}+3 \mathrm{H}_{2} \mathrm{~A}_{2} \rightleftharpoons\left(\mathrm{HA}_{2}\right)_{3(o)}+3 \mathrm{H}^{+}+3 \mathrm{NO}^{3-}
\end{aligned}
$$

The effectiveness of the entire process of the emulsion liquid membrane method can be seen by looking at the distribution coefficient and separation factors of $\mathrm{Y}$ and $\mathrm{Dy}$. The distribution 
coefficient is the ratio of the concentration of a compound in an immiscible two-phase mixture at equilibrium. While the separation factor is identical to the ratio of the distribution factor of the organic phase into the aqueous phase.

Based on Basuki \& Pamungkas's (2019) study, relatively good results were obtained at concentrations of $4-5 \%$ D2EHPA. The results showed that stripping efficiency increases due to the increasing number of complex compounds. The extraction efficiency and distribution coefficient for
$\mathrm{Y}$ and Dy were respectively $94.08 \%$ and 15.97 for $\mathrm{Y}$ and $67.85 \%$ and 2.11 for Dy with the value of the Y-Dy separator factor of 7. 57.

\section{Cyanex 302}

Another type of extractant that is often used in the emulsion liquid membrane process in REM extraction is Cyanex 302. Laguel \& Samar (2019) extracted Eu(III) using Cyanex 302 extractant as a carrier. The structure of the compound Cyanex 302 is shown in Figure 3.

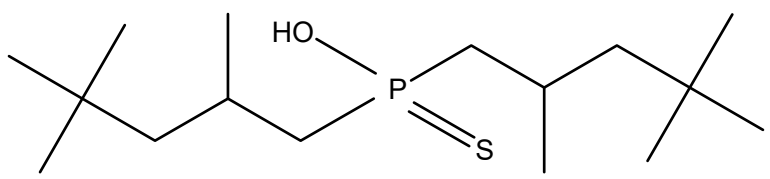

Figure 3. Structure of the compound Cyanex 302: bis-(2,4,4-trimethyl penthyl) monothiophosphate phosphate acid

The transport mechanism of $\mathrm{Eu}(\mathrm{III})$ by ELM method using Cyanex 302 as a carrier is shown in Figure 4.

In this case, the reactive compound (Cyanex $302)$ is in the membrane phase. The ligand is soluble in the membrane phase and insoluble in the external phase and the internal phase. In the outer phase/membrane phase interface, Cyanex 302 is formed selectively and reversibly with the solute $\mathrm{Eu}(\mathrm{III})$ forming a complex (Cyanex 302-Eu(III)) in the membrane (Figure 4). In the presence of a concentration gradient, the complex (Cyanex 302$\mathrm{Eu}(\mathrm{III}))$ diffuses through the membrane towards the internal membrane-phase interface. At this interface, the complex (Cyanex 302-Eu(III)) then reacts with the stripping agent present in the internal phase to form a complex with the transported solute $\mathrm{Eu}(\mathrm{III})$, which is more stable than the complex formed by the transporter (Cyanex 302). As a result of this reaction, there is a disconnection of the Cyanex 302-Eu(III) complex. Where the solute $\mathrm{Eu}(\mathrm{III})$ is permanently bound to the stripping agent, while the carrier (Cyanex 302) is regenerated and returned through the membrane to the external-membrane phase interface to transport the residual solute.

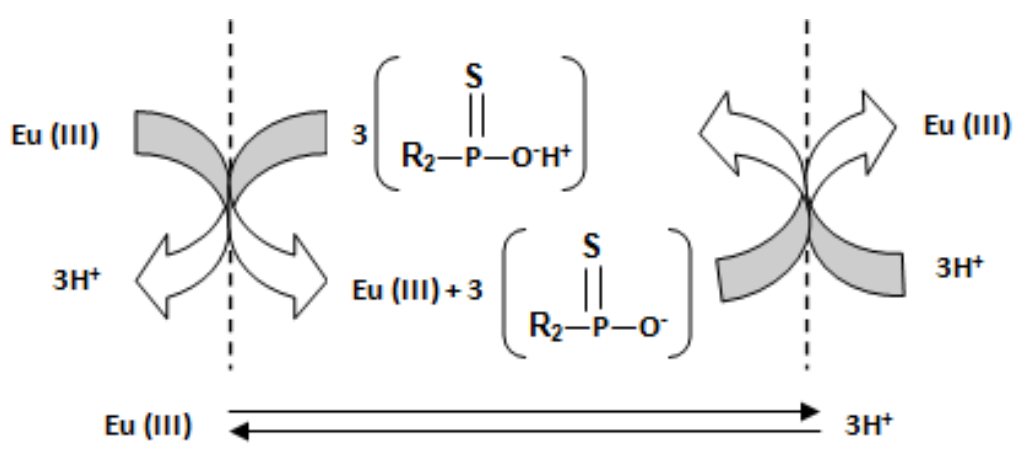

Figure 4. $\mathrm{Eu}(\mathrm{III})$ extraction mechanism in an emulsion liquid membrane system (adopted from research Laguel \& Samar, 2019) 
To study the effect of carrier concentration, Eu(III) ions were extracted using various Cyanex 302 concentrations. The Cyanex 302 concentration was varied from $0.05-0.9 \%(\mathrm{w} / \mathrm{w})$ with the optimum Cyanex 302 concentration of $0.3 \%(\mathrm{w} / \mathrm{w})$. The results obtained are shown in Figure 5.
From Figure 5 it has been proven that the carrier concentration has a significant effect on the recovery of $\mathrm{Eu}(\mathrm{III})$ from the aqueous phase. Thus, the extraction efficiency of $\mathrm{Eu}(\mathrm{III})$ using Cyanex 302 extractant was $92.68 \%$.

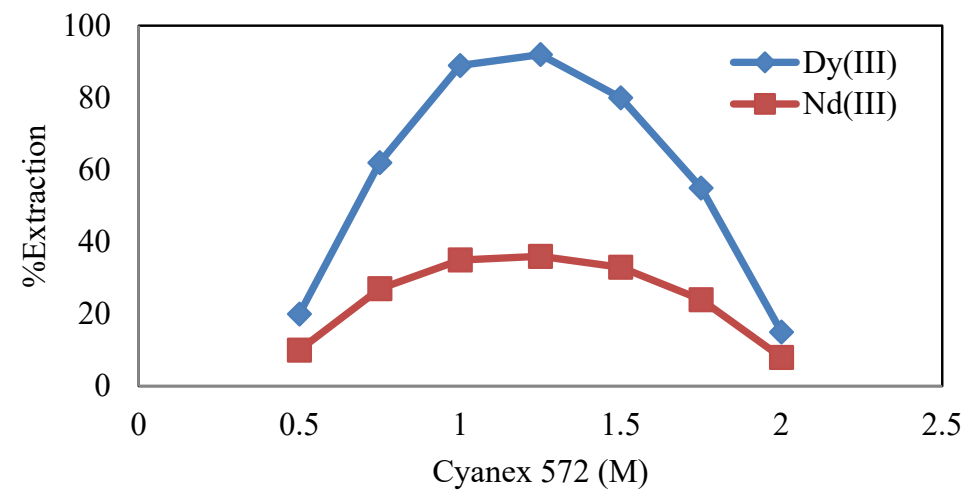

Figure 5. Effect of the carrier concentration on the extraction of $\mathrm{Eu}(\mathrm{III})$ in the ELM system (adopted from research Laguel \& Samar, 2019)

\section{Cyanex 572}

Cyanex 572 is a new type of organophosphorus extractant consisting of a mixture of phosphoric and phosphonic acids, it is stable and specially formulated for the separation and purification of individual REM (Wang et al., 2015). Cyanex 572 used can affect the acid concentration in the REM stripping to be lower due to the slightly higher extraction $\mathrm{pH}$. This, of course, leads to significant acid savings over time (Tunsu et al., 2016).

The extraction efficiency of REM can be increased by increasing the concentration of Cyanex 572 to a certain degree (Davoodi-nasab et al., 2018b). This can be explained by the presence of a free carrier at the feed-membrane phase interface and the unsaturated interface between the feed phase and the membrane phase, which results in the formation of more metal-Cyanex 572 complexes (Alpaydin et al., 2011; Othman et al., 2006).
The extraction efficiency and the REM separation factor are highly dependent on the acidity in the external phase solution. Extraction of REM occurs by replacing the extractant hydrogen ions. The difference in hydrogen ion concentration between the feed and stripping phases induces increased REM transport by increasing the $\mathrm{pH}$ value of the feed phase (Davoodi-nasab et al., 2018b). This shows that the rate of complexation of the REM ion with Cyanex 572 extractant as a cation exchanger is directly proportional to the acidity of the feed phase.

Raji et al. (2017b) conducted a study to determine the role of Cyanex 572 in the selectivity of $\mathrm{Dy}$ and $\mathrm{Nd}$, using various concentrations of Cyanex 572 in the range 0.5 to $2 \mathrm{M}$ with the optimum concentration of Cyanex 572 at $1.25 \mathrm{M}$. The variation of Cyanex 572 concentration on extraction efficiency shown in Figure 6.

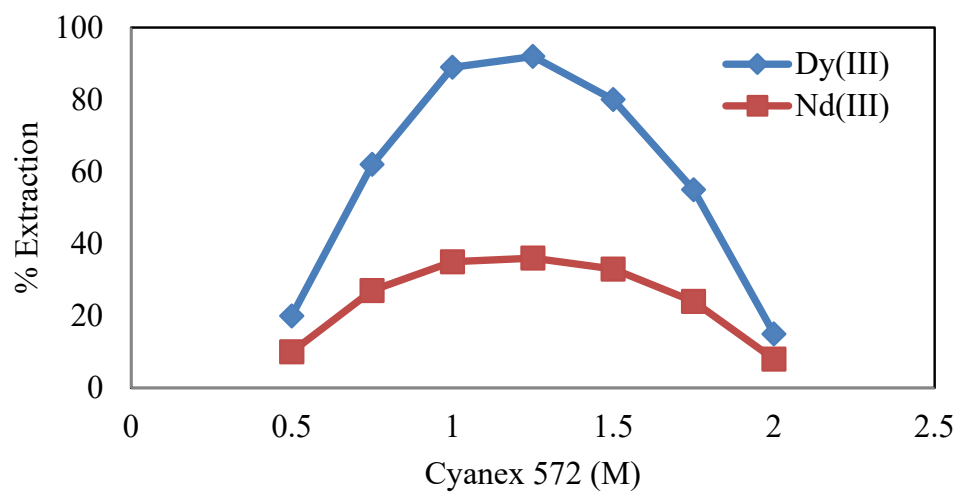

Figure 6. Effect of Cyanex 572 carrier concentration on Dy(III) and $\mathrm{Nd}(\mathrm{III})$ extraction (adopted from research Raji et al., 2017a) 
In the concentration range of $0.5-1.25 \mathrm{M}$ the extraction efficiency of Dy(III) increased from 22.16 to $95.98 \%$ and from 10.98 to $38.9 \%$ for $\mathrm{Nd}(\mathrm{III})$. This stems from the formation of many more extractant and metal complexes at the outer interface.

Furthermore, when the concentration was further increased from 1.25 to $2 \mathrm{M}$, the extraction efficiency and recovery value were lower. This can be attributed to an increase in membrane viscosity with an increase in extractant concentration leading to a lower diffusion of the metal complex through the membrane phase (Binnal \& Hiremath, 2012; Kulkarni \& Mahajani, 2002; Seifollahi \& RahbarKelishami, 2017). In addition, increasing the Cyanex 572 concentration can also increase membrane swelling, thereby diluting the stripping phase and decreasing the extraction efficiency and yield value of the ELM process (Kulkarni et al., 2000). According to these data, the maximum separation factor achieved when the concentration of Cyanex 572 was equal to $1.25 \mathrm{M}$. From Raji et al. (2017b) experiment, the extraction efficiency of Dy(III) was $98.99 \%$ and resulted in a good separation with a value of 19.56 for Dy(III) and 2.7 for $\mathrm{Nd}(\mathrm{III})$.

In addition, Davoodi-Nasab et al. (2018b) have also performed selective separation of Gd(III) and $\mathrm{Nd}(\mathrm{III})$ using Cyanex 572 with optimum concentration at $0.75 \mathrm{M}$ and obtained extraction efficiency of $67.45 \%$ for $\mathrm{Gd}(\mathrm{III})$ and $28.98 \%$ for $\mathrm{Nd}(\mathrm{III})$.

\section{$\mathrm{RO})_{2} \mathrm{P}(\mathrm{O}) \mathrm{OPh}-\mathrm{COOH}$}

Carboxylic acid group extractants are quite stable in hydrocarbon solvents. However, in low polarity solvents, it tends to associate and result in more complex speciations (García et al., 2013). This type of extractant has practical uses for REM processing because it is relatively inexpensive compared to other common extractants, is easy to obtain, and has been used in commercial processes for various purposes (Vahidi \& Zhao, 2017).

Chen et al. (2018), in their study, modified the D2EHPA extractant for obtained a new type of extractant $(\mathrm{RO})_{2} \mathrm{P}(\mathrm{O}) \mathrm{OPh}-\mathrm{COOH}$, which can show improved performance in the $\mathrm{REM}^{3+}$ extraction process. The structure of the compound $(\mathrm{RO})_{2} \mathrm{P}(\mathrm{O}) \mathrm{OPh}-\mathrm{COOH}$ is shown in Figure 7.

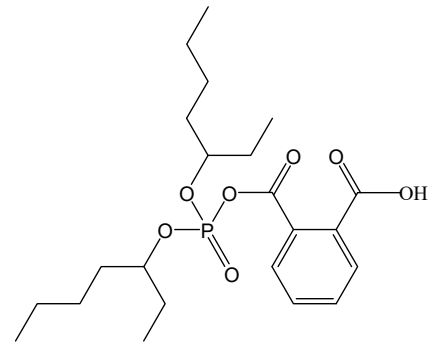

Figure 7. Structure of the compound $(\mathrm{RO})_{2} \mathrm{P}(\mathrm{O}) \mathrm{OPh}-\mathrm{COOH}$

To produce an effective transport system, one of the factors that are considered important is the type of extractant (carrier) that is suitable. As a comparison, the migration ability of D2EHPA, and $(\mathrm{RO})_{2} \mathrm{P}(\mathrm{O}) \mathrm{OPhCOOH}$ as carriers are shown in Figure 8.

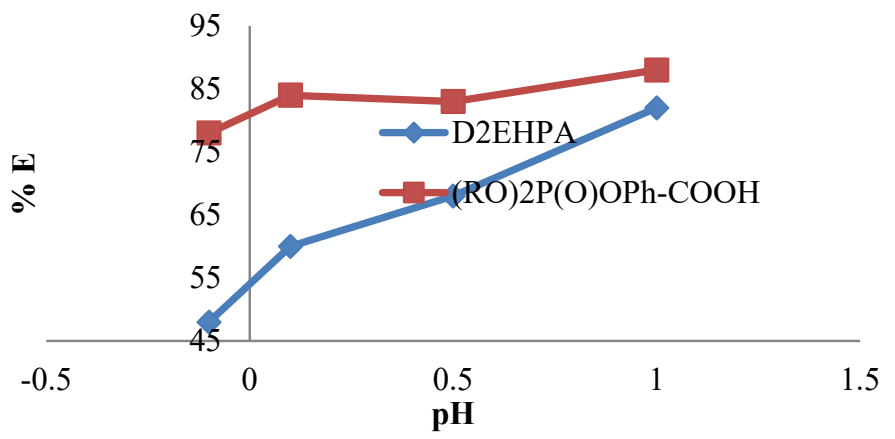

Figure 8. Effect of carrier and $\mathrm{pH}$ value on the extraction rate of $\mathrm{REM}^{3+}$ using ELM process (adopted from research Chen et al., 2018)

Figure 8 concluded that increasing the $\mathrm{pH}$ from 0.1 to 1.0 led to a significant increase in the extraction efficiency of $\mathrm{REM}^{3+}$. This means that the extraction is easier at a higher $\mathrm{pH}$. The extraction 
ability of D2EHPA under low acidity is determined by the acidity of the feed solution and is unstable in feed solutions with different acidities (Raji et al., 2017a; Hasan et al., 2009). The acidity $(\mathrm{RO})_{2} \mathrm{P}(\mathrm{O}) \mathrm{OPh}-\mathrm{COOH}$ is stronger than D2EHPA. As a carrier, $(\mathrm{RO})_{2} \mathrm{P}(\mathrm{O}) \mathrm{OPh}-\mathrm{COOH}$ is superior to D2EHPA because it can increase the atomic number distribution coefficient caused by the extraction of REM alkyl phosphoric acid with lanthanide elements, and its extraction capacity increases due to its benzene ring conjugation effect. When phthalic acid reacts with D2EHPA, it causes only one carboxyl reaction. The other carboxyl remains connected to the benzene, thereby increasing steric hindrance. Under highly acidic conditions, the electron density of the $\mathrm{P}=\mathrm{O}$ bond increases, and this change can increase the extraction performance (Krea \& Khalaf, 2000; Singh et al., 2004).

Based on Chen et al. (2018) study, the efficiency of $\mathrm{REM}^{3+}$ extraction using extractant $(\mathrm{RO})_{2} \mathrm{P}(\mathrm{O}) \mathrm{OPh}-\mathrm{COOH}$ reached $82.68 \%$. Extractant $(\mathrm{RO})_{2} \mathrm{P}(\mathrm{O}) \mathrm{OPh}-\mathrm{COOH}$ as a carrier has high selectivity for $\mathrm{REM}^{3+}$. Even more, under the optimal operating parameters, the demulsification (stripping) efficiency reaches more than 59\%.

\section{Aniline}

Amine extractants consisting of primary ammonium (Aniline) to quaternary are very efficient in separating radioactive elements and rare earth elements (Zhang et al., 2015). Amine extractants performed well with light REM groups. A suggested route for separation by amine extractants is an anion exchange mechanism (Coleman, 1963).

The complex formation mechanism that can be extracted can only occur when the nitrate ions in the solution are high (Cerna et al., 1992). In addition, ion dehydration from REM ion stripping can also contribute to an increase in the number of complexes that can be extracted. Hydration is higher in the light REM group and may continue to decrease throughout the lanthanide series (Marcus \& Abrahamer, 1961). The structure of the aniline compound is included in the primary amine shown in Figure 9.<smiles>Nc1ccccc1</smiles>

Figure 9. The structure of Aniline compound $\left(\mathrm{PhNH}_{2}\right)$

In the study conducted by Zhang et al. (2016a) concentration, and the extraction rate of aniline,
D2EHPA, and PC-88A as comparison extractants showed in Figure 10.

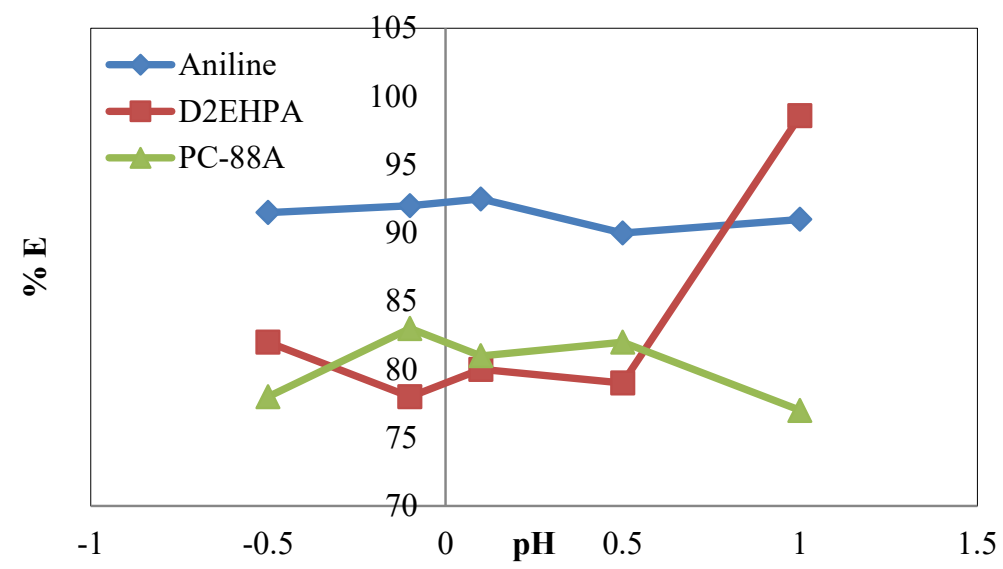

Figure 10. Extraction efficiency of REM ${ }^{3+}$ in the ELM system using D2EHPA

Figure 10 shows that the extraction efficiency of $\mathrm{REM}^{3+}$ in the ELM system using D2EHPA reaches
$98.64 \%$ at $\mathrm{pH}$ 1.0. However, the extraction rate decreases drastically at lower $\mathrm{pH}$ values. At $\mathrm{pH}-0.5$, 
the extraction rate is $82.23 \%$. While the variation in $\mathrm{pH}$ using PC-88A as a carrier has a small effect on ELM properties and the extraction efficiency fluctuates around 80\%. Zhang et al. (2016a) chose Aniline as a carrier because the extraction abilities of D2EHPA and PC-88A were less stable than Aniline when the acidity of the REM solution was changed. this can be caused by a different reaction mechanism For D2EHPA and PC-88A with low acidity, $\mathrm{H}^{+}$ which dissociates from the hydroxyl groups in D2EHPA and PC-88A can be exchanged for $\mathrm{REM}^{3+}$. In addition, the $\mathrm{P}=\mathrm{O}$ bond tends to coordinate with $\mathrm{REM}^{3+}$. When the $\mathrm{pH}$ is set to a lower level (high acidity), there will be less $\mathrm{H}^{+}$in the solution to interact with $\mathrm{REM}^{3+}$. As for the extraction ability, D2EHPA is better than PC-88A because there are no C-P bonds in the molecular structure of D2EHPA, then it has lower electronegativity, and higher acidity Aniline is a primary amine. Under acidic conditions, the amine extractant will be protonated into ammonium cations then form an anion complex with the ammonium ion. The extraction mechanism using aniline extractant is explained by Equations (5) and (6) (Zhang et al., 2016a):

$$
\begin{aligned}
& \mathrm{PhNH}_{2}+\mathrm{H}^{+}+\mathrm{Cl}^{-} \rightleftharpoons \mathrm{PhNH}_{3} \mathrm{Cl} \\
& \mathrm{PhNH}_{3} \mathrm{Cl}+\left[\mathrm{RECl}_{4}\right]^{-} \rightleftharpoons \mathrm{PhNH}_{3}\left[\mathrm{RECl}_{4}\right]+\mathrm{Cl}^{-}
\end{aligned}
$$

The variation of aniline concentrations was carried out in the range of $4-14 \%$, with the optimum concentration of Aniline, which was $6 \%$, where the extraction efficiency obtained was 93.21\%. Increasing the Aniline concentration beyond $6 \%$ will decrease the extraction efficiency. Increasing the extractant (carrier) concentration within a certain range contributes to reducing the viscosity of ELM; however, an excessive concentration of the carrier will reduce the ELM stability (Yan \& Pal, 2001; Clausse et al., 1999).

TBP

TBP (tributyl phosphate) is a type of organophosphorus extractant that is widely used in industry for the separation and purification of REM ions because of its high ability to extract, stable to acids, and easily obtained (Purwani \& Biyantoro, 2013).

Tributyl phosphate (TBP) ligand has the chemical formula $\left(\mathrm{C}_{4} \mathrm{H}_{9}\right)_{3} \mathrm{PO}_{4}$, is in the form of a liquid, colorless, or faded yellow with a molecular weight of $266.318 \mathrm{~g} / \mathrm{mol}$ and a specific gravity of $0.9727 \mathrm{~g} / \mathrm{mL}$. TBP is a neutral organophosphate compound, contains three butyl groups, and has 1 donor oxygen atom in the $\mathrm{P}=\mathrm{O}$ group, which can coordinate with metal ions by donating its lone pair to the empty metal ion orbital to be separated (Aryadi, 2011). The structure of TBP is shown in Figure 11.

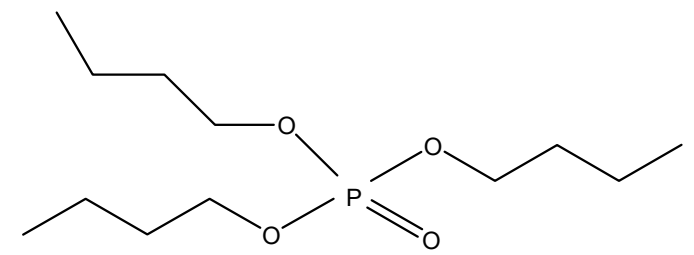

Figure 11. The structure of tributyl phosphate compound

In their research, Purwani \& Biyantoro (2013) conducted Th-Ce separation using TBP extractant in the ELM system. The reaction that occurs between REM in nitric acid and TBP extractant follows the cation exchange reaction as in equations (7), (8), and (9) as follows (Zhou, 2012):

$$
\begin{aligned}
& \mathrm{Ce}(\mathrm{OH})_{4}+4 \mathrm{HNO}_{3} \rightarrow \mathrm{Ce}\left(\mathrm{NO}_{3}\right)_{4}+4 \mathrm{H}_{2} \mathrm{O} \\
& \mathrm{HNO}_{3(\mathrm{o})}+\mathrm{TBP}_{(\mathrm{o})} \rightleftharpoons \mathrm{HNO}_{3} \cdot \mathrm{TBP}_{(\mathrm{o})} \\
& \mathrm{Ce}^{4+}+4\left(\mathrm{HNO}_{3} \cdot \mathrm{TBP}\right) \rightleftharpoons \mathrm{Ce}\left(\mathrm{NO}_{3}\right)_{4} \cdot 4 \mathrm{TBP}_{(\mathrm{o})}+4 \mathrm{H}^{+}
\end{aligned}
$$

While the reaction that occurs in the stripping phase with phosphoric acid is shown in equation (10) as follows (Purwani \& Biyantoro, 2013):

$$
3 \mathrm{Ce}\left(\mathrm{NO}_{3}\right)_{4} .4 \mathrm{TBP}+4 \mathrm{H}_{3} \mathrm{PO}_{4} \rightarrow \mathrm{Ce}_{3}\left(\mathrm{PO}_{4}\right)_{4}+12 \mathrm{TBP}+12 \mathrm{HNO}_{3}
$$

The concentration of TBP used greatly influenced the extraction of separated metals. In the Purwani \& Biyantoro (2013) study, the TBP concentration was varied from $5-30 \%$. Figure 12 shows the correlation between \% TBP and the extraction efficiency of $\mathrm{Ce}$ and $\mathrm{Th}$.
Figure 12 shows that the greater the \% TBP, the better the extraction efficiency. This shows that the reaction between $\mathrm{Ce}$ and Th with TBP is getting more complete. However, when using \% TBP exceeding $15 \%$, the extraction efficiency does not increase. This can be due to the increased viscosity 
of the organic phase, which can inhibit the mass transfer of $\mathrm{Ce}$ and $\mathrm{Th}$ from the feed phase to the membrane phase. The correlation between \% TBP and stripping efficiency is shown in Figure 13.

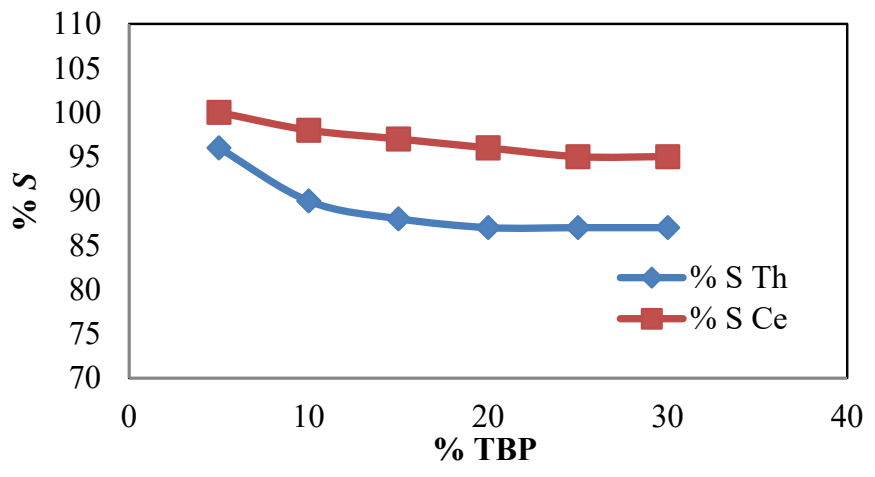

Figure 12. The correlation between \% TBP and stripping efficiency of Th and Ce (adopted from research Purwani \& Biyantoro, 2013)

Figure 12 shows that as the \% TBP increases, the stripping efficiency tends to decrease. This can be since there is still an internal aqueous phase trapped in the membrane phase so that the volume of the internal aqueous phase decreases, which causes the amount of $\mathrm{Ce}$ and $\mathrm{Th}$ in the internal aqueous phase to be less. In addition, as the \% TBP increases, the amount of $\mathrm{Ce}$ and $\mathrm{Th}$ in the membrane phase increases. This can lead to a decrease in the stripping efficiency because the less amount of acid from the internal phase can react with $\mathrm{Ce}$ and $\mathrm{Th}$, so there are only a few ions $\mathrm{Ce}$ and Th were stripped into the internal phase. The correlation between \% TBP and the separation factor (SF) of Ce-Th is shown in Figure 14.

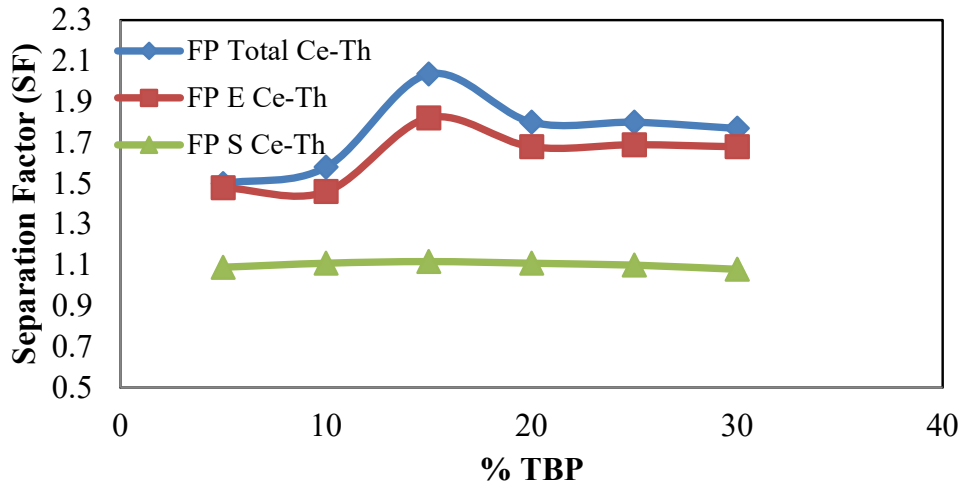

Figure 13. The correlation between \% TBP and Ce-Th separation factor (adopted from research Purwani \& Biyantoro, 2013)

Figure 13 shows that with $5-15 \%$ TBP concentration used, separation factor (SF) extraction and SF stripping Ce-Th increased so that the total SF Ce-Th also increased. However, when the TBP concentration exceeds $15 \%$, SF Ce-Th decreases. So it concluded that $15 \%$ is the optimum concentration for TBP in the separation of Th from Ce. In this separation, $\% \mathrm{E} \mathrm{Ce}=84.54 \%, \% \mathrm{Ce}=$ $98.05 \%$ and $\% \mathrm{E} \mathrm{Th}=46.41 \%$, \%S Th $=87.68 \%$ were obtained. In addition, it was obtained SF of Ce-Th extraction $=1.8216$, SF stripping Ce-Th $=$ 1,1177 , and total SF Ce-Th $=2.036$.

Table 1 shows a summary of the various concentrations and types of extractants on the extraction and stripping efficiency in the separation of REM using the ELM (Emulsion Liquid Membrane) method. 
Table 1. Types of extractants and various concentrations on REM separation

\begin{tabular}{|c|c|c|c|c|c|}
\hline Methode & REM & $\begin{array}{l}\text { Extractants } \\
\text { Types }\end{array}$ & $\begin{array}{c}\text { Extractants } \\
\text { Concentration }\end{array}$ & $\% \mathrm{E}$ & $\% \mathrm{~S}$ \\
\hline \multirow{9}{*}{ ELM } & $\begin{array}{l}\text { Eu(III) (Laguel \& } \\
\text { Samar, 2019) }\end{array}$ & Cyanex 302 & $0.3 \%(\mathrm{w} / \mathrm{w})$ & 92.68 & - \\
\hline & $\begin{array}{l}\text { Y(III) (Basuki \& } \\
\text { Pamungkas, 2019) }\end{array}$ & D2EHPA & $4.5 \%(\mathrm{v} / \mathrm{v})$ & 94.08 & 92.28 \\
\hline & $\begin{array}{l}\text { Gd(III) (Davoodi- } \\
\text { Nasab et al., 2018a) }\end{array}$ & D2EHPA & $0.05 \mathrm{M}$ & 99 & 79 \\
\hline & $\begin{array}{l}\text { Nd(III) Gd(III) } \\
\text { (Davoodi-Nasab, et } \\
\text { al., 2018b) }\end{array}$ & Cyanex 572 & $0.75 \mathrm{M}$ & $\begin{aligned} \mathrm{Gd} & =67.45 \\
\mathrm{Nd} & =28.98\end{aligned}$ & $\begin{aligned} \mathrm{Gd} & =89.04 \\
\mathrm{Nd} & =19.45\end{aligned}$ \\
\hline & $\begin{array}{l}\text { REM(III) (Chen, et } \\
\text { al., 2018) }\end{array}$ & $\begin{array}{c}(\mathrm{RO})_{2} \mathrm{P}(\mathrm{O}) \mathrm{OPh}- \\
\mathrm{COOH}\end{array}$ & $12 \%(\mathrm{v} / \mathrm{v})$ & 82.68 & 59 \\
\hline & $\begin{array}{l}\text { Dy(III) (Raji, et al., } \\
\text { 2017b) }\end{array}$ & D2EHPA & $0.05 \mathrm{M}$ & 99.6 & 85.22 \\
\hline & $\begin{array}{l}\text { Dy(III) (Raji, et al., } \\
\text { 2017a) }\end{array}$ & Cyanex 572 & $1.25 \mathrm{M}$ & 98.99 & - \\
\hline & $\begin{array}{l}\text { REM(III) (Zhang, et } \\
\text { al., 2016) }\end{array}$ & Aniline & $6 \%(\mathrm{v} / \mathrm{v})$ & 93.21 & - \\
\hline & $\begin{array}{l}\text { Th-Ce (Purwani \& } \\
\text { Biyantoro, 2013) }\end{array}$ & TBP & $15 \%(\mathrm{v} / \mathrm{v})$ & $\begin{array}{l}\mathrm{Ce}=84.54 \\
\mathrm{Th}=46.41\end{array}$ & $\begin{array}{l}\mathrm{Ce}=98.05 \\
\mathrm{Th}=87.68\end{array}$ \\
\hline
\end{tabular}

\section{Conclusions}

The separation process of rare earth metals in the emulsion liquid membrane (ELM) system is strongly influenced by the concentration of various types of extractants used because it plays an important role in the transport properties and membrane stability. The optimum extractant concentration ranges from $0.05-15 \% \mathrm{v} / \mathrm{v}$ depending on the conditions of other parameters such as the $\mathrm{pH}$ of the feed phase, the time of extraction stirring, and the acidity of the stripping phase. The extractant concentration used must be optimized to obtain high extraction efficiency and stripping efficiency. The extraction efficiency of REM can be increased by increasing the extractant concentration to a certain degree. Too high or too low the extractant concentration can decrease the extraction and stripping efficiency. A good extractant must have a positive selectivity to the desired REM, excellent chemical stability, low density and viscosity, and low solubility in the aqueous phase.

\section{Acknowledgments}

The author gratefully acknowledges the support from the ALG (Academic Leadership Grant) project (1427/UN6.3.1/LT/2020), as well as to Dr. Anni Anggraeni, M.Si, and Dr. Eng. Uji Pratomo, M.Si as the supervisor who has helped a lot in writing this review journal.

\section{References}

Alpaydin, S., Saf, A. Ö., Bozkurt, S., \& Sirit, A. (2011). Kinetic study on removal of toxic metal $\mathrm{Cr}(\mathrm{VI})$ through a bulk liquid membrane containing p-tertbutylcalix[4] arene derivative. Desalination, 275(1-3), 166-171.

Anitha, M., Ambare, D. N., Singh, D. K., Singh, H., \& Mohapatra, P. K. (2015). Extraction of neodymium from nitric acid feed solutions using an emulsion liquid membrane containing TOPO and DNPPA as the carrier extractants. Chemical Engineering Research and Design, 98(June), 89-95.

Aryadi, S. (2011). Ekstraksi torium dari konsentrat Th, LTJ (Hidroksida) menggunakan solven Bis-2-Etil Heksil Fosfat. Prosiding Seminar Penelitian Dan Pengelolaan Perangkat Nuklir (pp. 40-47). Yogyakarta: Badan Tenaga Nulir Nasional.

Asnani, C., \& Patra, R. (2013). Rare earth from monazite - Indian experience. Conference of Metallurgist (pp. 167-172). Montreal: Canadian Institute of Mining, Metallurgy and Petroleum.

Balasubramanian, A. (2017). Box-Behnken modelling of phenol removal from aqueous solution using emulsion liquid membrane. International Research Journal of Engineering and Technology (IRJET), 04(07), 489-493. 
Basuki, K. T., \& Pamungkas, N. S. (2019). Separation factor of Y/Dy emulsion on membrane process using nitric acid and D2EHPA solvent. Indonesian Journal of Chemistry, 19(4), 865-872.

Binnal, P., \& Hiremath, P. G. (2012). Application of liquid emulsion membrane technique for the removal of $A s(V)$ from aqueous solutions. Journal of the Institution of Engineers (India) Series E, 93(March), 1-8.

Binnemans, K., Jones, P. T., Blanpain, B., Gerven, T. V., Yang, Y. X., Walton, A., \& Buchert, M. (2013). Recycling of rare earth: A critical review. Journal of Cleaner Production, 51(July), $1-22$.

Cerna, M., Volaufova, E., \& Rod, V. (1992). Extraction of light rare earth elements by amines at high inorganic nitrate concentration. Hydrometallurgy, 28(3), 339-352.

Chakraborty, M., Bhattacharya, C., \& Datta, S. (2010). Emulsion liquid membranes: Definitions and classification, theories, module design, applications, new directions and perspectives. In Vladimir S. Kislik (Eds.), Liquid Membranes: Principles and Applications in Chemical Separations and Wastewater Treatment (pp. 141-199). New York: Elsevier.

Chaouchi, S., \& Hamdaoui, O. (2014). Extraction of priority pollutant 4-nitrophenol from water by emulsion liquid membrane: emulsion stability, effect of operational conditions and membrane reuse. Journal of Dispersion Science and Technology, 35(9), 1278-1288.

Chaouchi, S., \& Hamdaoui, O. (2015). Extraction of endocrine disrupting compound propylparaben from water by emulsion liquid membrane using trioctylphosphine oxide as carrier. Journal of Industrial Engineering. Chemistry, 22(February), 296-305.

Chen, L., Wang, Y., Yuan, X., Ren, Y., Liu, N., Yuan, L., \& Feng, W. (2018). Highly selective extraction of uranium from nitric acid medium with phosphine oxide functionalized pillar[5] arenes in room temperature ionic liquid. Separation and Purification Technology, 192(February), 152-159.

Choudhury, A., Sengupta, S., Bhattacharjee, C., \& Datta, S. (2010). Extraction of hexavalent chromium from aqueous Stream by emulsion liquid membrane (ELM). Separation Science and Technology, 45(2), 178-185.

Clausse, D., Pezron, I., \& Komunjer, L. (1999). Stability of W/O and W/O/W emulsions as a result of partial solidification. Colloids Surfaces: Physicochemical and Engineering Aspect, 152(12), 23-29.

Coleman, C. F. (1963). Amine as extractants. Nuclear Science and Engineering, 17(2), 274286.
Davoodi-Nasab, P., Rahbar-Kelishami, A., Safdari, J., \& Abolghasemi, H. (2018a). Evaluation of the emulsion liquid membrane performance on the removal of gadolinium from acidic solutions. Journal of Molecular Liquids, 262, 97-103.

Davoodi-Nasab, P., Rahbar-kelishami, A., Safdari, J., \& Abolghasemi, H. (2018b). Selective separation and enrichment of neodymium and gadolinium by emulsion liquid membrane using a novel extractant CYANEX ${ }^{\circledR} 572$. Minerals Engineering, 117(March), 63-73.

García, M. G., Acosta, A. O., \& Marchese, J. (2013). Emulsion liquid membrane pertraction of $\mathrm{Cr}$ (III) from aqueous solutions using PC$88 \mathrm{~A}$ as a carrier. Desalination, 318(June), 8896.

Gupta, C. K., \& Krishnamurthy, N. (2005). Extractive metallurgy of rare earth. Florida: CRC Press.

Hasan, M. A., Aglan, R. F., \& El-Reefy, S. A. (2009). Modeling of gadolinium recovery from nitrate medium with 8-hydroxyquinoline by emulsion liquid membrane. Journal of Hazardous Material, 166(2-3), 1076-1081.

Hirai, T., \& Orikoshi, T. (2004). Preparation of $\mathrm{Gd}_{2} \mathrm{O}_{3}: \mathrm{Yb}, \mathrm{Er}$ and $\mathrm{Gd}_{2} \mathrm{O}_{2} \mathrm{~S}: \mathrm{Yb}$, Er infrared-tovisible conversion phosphor ultrafine particles using an emulsion liquid membrane system. Journal of Colloid and Interface Science, 269(1), 103-108.

Hoenderdaal, S., Espinoza, L. T., \& MarscheiderWeidemann, F. M., \& Graus, W. (2013). Can a dysprosium shortage threaten green energy technologies?. Energy, 49(January), 344-355.

Ismail, N. A., Aziz, M. A. A., Yunus, M. Y. M., \& Hisyam, A. (2019). Selection of extractant in rare earth solvent extraction system : A review. International Journal of Recent Technology and Engineering (IJRTE), 8(1), 728-743.

Jolly, H. J. (1975). Rare earth elements and yttrium, mineral facts and problems. US: Bureau of Mines.

Kargari, A. (2013). Simultaneous extraction and stripping of 4-chlorophenol from aqueous solutions by emulsion liquid membrane. Desalinination and Water Treatment, 51(1012), 2275-2279.

Kolev, S. D. (2005). Membranes techniques: Liquid membranes. In P. Worsfold, A. Townshend, C. Poole (Eds.), Encyclopedia of Analytical Science (pp 531-538). Amsterdam: Elsevier.

Krea, M., \& Khalaf, H. (2000). Liquid-liquid extraction of uranium and lanthanides from phosphoric acid using a synergistic DOPPATOPO mixture. Hydrometallurgy, 58(3), 215225.

Kulkarni, P. S., \& Mahajani, V. V. (2002). Application of liquid emulsion membrane (LEM) process for enrichment of molybdenum 
from aqueous solutions. Journal of Membrane Science, 201(1-2), 123-135.

Kulkarni, P. S., Tiwari, K. K., \& Mahajani, V. V. (2000). Membrane stability and enrichment of nickel in the liquid emulsion membrane process. Journal of Chemical Technology and Biotechnology, 75(7), 553-560.

Kumbasar, R. A. (2008). Transport of cadmium ions from zinc plant leach solutions through emulsion liquid membrane-containing aliquat 336 as a carrier. Separation and Purification Technology, 63(3), 592-599.

Kumbasar, R. A., \& Tutkun, O. (2006). Selective separation of gallium from acidic leach solutions by emulsion liquid membranes. Separation Science Technology, 41(12), 28252847.

Laguel, S., \& Samar, M. E. (2019). Removal of europium(III) from water by emulsion liquid membrane using cyanex 302 as a carrier. Desalination and Water Treatment, 165, 269280.

Laki, S., Shamsabadi, A. A., Madaeni, S. S., \& Niroomaneshd, M. (2015). Separation of manganese from aqueous solution using emulsion liquid membrane. RSC Advances, 5(102), 84195-84206.

Larquet, E., Dragoe, D., Serra, O. A., \& Gacoin, T. (2017). Lanthanoid-doped phosphate/vanadate mixed hollow particles as ratiometric luminescent sensors. ACS Applied Material \& Interfaces, 9(2), 1635-1644.

Liang, P., Liming, W., \& Guoqiang, Y. (2011). Separation of Eu(III) with supported dispersion liquid membrane system containing D2EHPA as carrier and $\mathrm{HNO}_{3}$ solution as stripping solution. Journal of Rare Earths, 29(1), 7-14.

Marcus, Y., \& Abrahamer, I. (1961). Anion exchange of metal complexes-VII The lanthanides-nitrate system. Journal of Inorganic and Nuclear Chemistry, 22(1-2), 141-150.

Othman, N., Mat, H., \& Goto, M. (2006). Separation of silver from photographic wastes by emulsion liquid membrane system. Journal of Membrane Science, 282(1-2), 171-177.

Perera, J. M., \& Stevens, G. W. (2008). Use of emulsion liquid membrane systems in chemical and biotechnological separations. In Anil, K. Pabby, Syed S.H. Rizvi, \& Ana Maria Sastre Requena (Eds.), Handbook of Membrane Separations: Chemical, Pharmaceutical, Food, and Biotechnological Applications (pp 709-735) London: Taylor \& Francis Group.

Purwani, M. V, \& Biyantoro, D. (2013). Ekstraksi pemisahan Th-Ce dari Ce hidroksida hasil olah monasit menggunakan membran emulsi cair dengan solven TBP. Jurnal Teknologi Bahan Nuklir, 9(2), 94-107.

Pusztai, P., Simon, T., Kukovecz, Á., \& Kónya, Z. (2013). Structural stability test of hexagonal
$\mathrm{CePO}_{4}$ nanowires synthesized at ambient temperature. Journal of Molecular Structure, 1044(July), 94-98.

Raji, M, Abolghasemi, H., Safdari, J., \& Kargari, A. (2017a). Selective extraction of dysprosium from acidic solutions containing dysprosium and neodymium through emulsion liquid membrane by Cyanex 572 as carrier. Journal of Molecular Liquids, 254(March), 108-119.

Raji, M, Abolghasemi, H., Safdari, J., \& Kargari, A. (2017b). Pertraction of dysprosium from nitrate medium by emulsion liquid membrane containing mixed surfactant system. Chemical Engineering and Processing - Process Intensification, 120(October), 184-194.

Ritcey, G. M., \& Ashbrook, A. W. (1979). Solvent extraction: principles and applications to process metallurgi part II. New York: Elsevier Scientivic Publishing Company.

Sabry, R., Hafez, A., Khedr, M., \& El-Hassanin, A. (2007). Removal of lead by an emulsion liquid membrane. Desalination, 212(1-2), 165-175.

Sari, D. I. P. (2017). Optimasi proses pembuatan disporsium (dy) oksida dari konsentrat itrium hasil olah pasir senotim dengan metode ekstraksi. Unpublished Thesis (S1). Yogyakarta: Universitas Negeri Yogyakarta.

Sato, T. (1989). Liquid-liquid extraction of rareearth elements from aqueous acid solutions by acid organophosphorus compounds. Hydrometallurgy, 22(1-2), 121-140.

Seifollahi, Z., \& Rahbar-Kelishami, A. (2017). Diclofenac extraction from aqueous solution by an emulsion liquid membrane: Parameter study and optimization using the response surface methodology. Journal of Molecular Liquids, 231(April), 1-10.

Setyadji, M., \& Purwani, M. V. (2018). Solvent selection for extraction of neodymium concentrates of monazite sand processed product.Journal of Physic: Conference Series, 962, 1-13.

Singh, H., Mishra, S. L., \& Vijayalakshmi, R. (2004). Uranium recovery from phosphoric acid by solvent extraction using a synergistic mixture of di-nonyl phenyl phosphoric acid and tri-n-butyl phosphate. Hydrometallurgy, 73(12), 63-70.

Srinivasan, G. S., Shivaramaiah, R., Kent, P. R. C., Stack, A. G., Riman, R., Anderko, A., Navrotsky, A., \& Bryantsev. V. S. (2017). A comparative study of surface energies and water adsorption on Ce-bastnasite, La-bastnasite, and calcite via density functional theory and water adsorption calorimetry. Physical Chemistry Chemical Physics, 19(11), 7820-7832.

Suprapto, S. J. (2009). Tinjauan tentang unsur tanah jarang. Buletin Sumber Daya Geologi, $4(1), 36-45$. 
Swain, B., \& Otu, E. O. (2011). Competitive extraction of lanthanides by solvent extraction using Cyanex 272: Analysis, classification and mechanism. Separation Purification and Technology, 83(November), 82-90.

Tunsu, C., Lapp, J. B., Ekberg, C., \& Retegan, T. (2016). Selective separation of yttrium and europium using cyanex 572 for applications in fluorescent lamp waste processing. Hydrometallurgy, 166(December), 98-106.

Vahidi, E., \& Zhao, F. (2017). Environmental life cycle assessment on the separation of rare earth oxides through solvent extraction. Journal of Environmental Management, 203(December), 255-263.

Wang, F., Wang, W. B., Zhu, Y., \& Wang, A. (2017). Evaluation of $\mathrm{Ce}(\mathrm{III})$ and Gd(III) adsorption from aqueous solution using CTSg-(AA-co-SS)/ISC hybrid hydrogel adsorbent. Journal of Rare Earths, 35(7), 697-708.

Wang, Y., Li, F., Zhao, Z., Dong, Y., \& Sun, X. (2015). The novel extraction process based on CYANEX $^{\oplus} 572$ for separating heavy rare earths from ion-adsorbed deposit. Separation and Purification and Technology, 151(September), 303-308.

Wannachod, T., Leepipatpiboon, N., Pancharoen, U., \& Phatanasri, S. (2015a). Mass transfer and selective separation of neodymium ions via a hollow fiber supported liquid membrane using PC88A as extractant. Journal Industrial and Engineering. Chemistry, 21(January), 535-541.

Wannachod, T., Mohdee, V., Suren, S., Ramakul, P., Pancharoen, U., \& Nootong, K. (2015b). The separation of $\mathrm{Nd}(\mathrm{III})$ from mixed rare earth via hollow fiber supported liquid membrane and mass transfer analysis. Journal Industrial and Engineering Chemistry, 26(June), 214-217.

Yan, J., \& Pal, R. (2001). Osmotic swelling behavior of globules of $\mathrm{W} / \mathrm{O} / \mathrm{W}$ emulsion liquid membranes. Journal of Membrane Science, 190(1), 79-91.

Yoon, H. S., Kim, C. . J., Chung, K. W., Kim, S. D., \& Kumar, J. R. (2015). Process development for recovery of dysprosium from permanent magnet scraps leach liquor by hydrometallurgical techniques. Canadian Metallurgy Quarterly, 54(3), 318-327.

Zhang, L., Chen, Q., Kang, C., Ma, X., \& Yang, Z. (2016a). Rare earth extraction from wet process phosphoric acid by emulsion liquid membrane. Journal of Rare Earths, 34(7), 717-723.

Zhang, J., Zhao, B., \& Schreiner, B. (2016b). Rare earth beneficiation and hydrometallurgical processing. In Jack Zhang, Baodong Zhao, \& Bryan, Schreiner (Eds.), Separation Hydrometallurgy of Rare Earth Elements (pp 19. 54). New York: Springer.

Zhang, Z., Jia, Q., \& Liao, W. (2015). Progress in the separation processes for rare earth resources. In Jean-Claude Bünzli, \& Vitalij K. Pecharsky (Eds.), Handbook on the Physic and Chemistry Rare Earths Volume 48 (pp 287-376). London: Elsevier.

Zhou, Z., Qin. W., Fei, W., \& Li, Y. (2012). A study on stoichiometry of complexes of tributyl phosphate and methyl isobutyl ketone with lithium in the presence of $\mathrm{FeCl}_{3}$. Chinese Journal of Chemical Engineering, 20(1), 36-39. 